\title{
Usynlige studerende i åbne online forløb
}

\author{
Nye muligheder for efteruddannelse
}

Christian Dalsgaard, Aarhus Universitet

Tom Gislev, Aarhus Universitet

\begin{abstract}
Formålet med artiklen er at undersøge og diskutere, hvordan såkaldte usynlige studerende deltager i åbne online forløb, og hvordan og hvad de lærer. Usynlige studerende betegner i denne artikel de deltagere, der er inaktive, tilsyneladende falder fra, og som ikke gennemfører de obligatoriske kursusaktiviteter. Artiklen indledes med et overbliksreview af central litteratur inden for "open education" med særligt fokus på målet om at nå målgrupper, der ikke nås gennem traditionel uddannelse. Artiklen er baseret på et kvalitativt studie, som er funderet i 11 interviews og 51 spørgeskemabesvarelser. Analysen udpeger fem forskellige måder at deltage på i et online undervisningsforløb: Studerende, deltagere, medlemmer, observatører og gæester. Artiklen sætter i analysen af den empiriske undersøgelse fokus på, hvad og hvordan de usynlige studerende lærer gennem åbne online forløb. Analysen leder frem til fem centrale aktiviteter for usynlige studerendes læring: 1) at læse og se indhold, 2) at følge med og være en del af, 3) deltage i netværk, 4) reflektere og 5) anvende og ibrugtage. Endelig peger analysen på tre centrale former for udbytte for de usynlige studerende: 1) faglig inspiration, 2) at blive opdateret, samt 3) at få input til egen praksis. Resultaterne peger på, at der især er muligheder $\mathrm{i}$ at udvikle nye efteruddannelses-formater, der kan bidrage til usynlige studerendes egen kontekst - uden at etablere traditionelle kursusforløb med fastlagt læaringsmål.
\end{abstract}

\section{Engelsk abstract}

The objective of the paper is to examine different kinds of participation in open online courses with a specific focus on participants who are seemingly inactive and possibly drop out during the course. In the paper, this group is termed invisible students. The paper begins with an overview review of key literature within "open education" and the tradition of offering education to people with limited access to the traditional educational system. The paper is based on a qualitative study including 11 interviews and 51 questionnaire responses. The analysis identifies five different kinds of participation in an online course: students, participants, members, observers and visitors. In the analysis, the paper examines what and how invisible students learn in open online courses. The analysis identifies a number of key activities for invisible students: reading and watching content, following and being part of, participating in networks, reflecting, and utilising. Finally, the analysis shows that inspiraton, being updated and getting input for your own practice are key objectives for the invisible students in the online course. The results indicate that there are opportunities for developing new further education formats that can add value to invisible students' own context without determining the learning objectives. 


\section{Indledning}

Formålet med artiklen er at undersøge og diskutere, hvordan såkaldte usynlige studerende deltager i åbne online forløb, og hvordan og hvad de lærer. Usynlige studerende betegner i denne artikel de deltagere, der ikke gennemfører de obligatoriske kursusaktiviteter (såsom at besvare opgaver og bidrage til diskussioner), og som heller ikke tager eksamen. Denne gruppe får ofte tilknyttet betegnelser som frafaldne, inaktive eller uengagerede. Det er især inden for Massive Open Online Courses (MOOCs), at det er relevant at studere usynlige studerende. Ifølge Jordan (J ordan, 2014) gennemfører langt størstedelen af MOOC-deltagere - op imod $90 \%$ - ikke kurserne. Ofte fremhæves denne meget lave gennemførelsesprocent som den største udfordring og mangel ved MOOCs (Daniel, 2012; Clow, 2013; Simpson, 2013). Imidlertid vil vi i denne artikel argumentere for, at netop denne store gruppe af deltagere er uddannelsesmæessig interessant. Artiklen tager afsæt i en hypotese om, at disse deltagelsesformer er udtryk for nye måder at lære på eller blive uddannet og opkvalificeret på. I artiklen præesenteres en undersøgelse af en MOOC, der var designet specifikt til at imødekomme forskellige deltagelsesformer. Målene med undersøgelsen var at identificere forskellige deltagelsesformer samt at afdække, hvordan og hvad gruppen af usynlige studerende lærer.

\section{Overbliksreview}

Åben uddannelse eller "open education" har i mange år haft som primært sigte at tilbyde uddannelse til de mennesker, der af forskellige årsager har haft en begræenset adgang til traditionel uddannelse (McAndrew, 2010; Littlejohn \& Pegler, 2014). Dette har især været formålet og motivationen bag etableringen af åbne universiteter i 1960,'erne mest prominent med oprettelsen af Open University i Storbritannien i 1969.

Med “Education for all”-rammen fra år 2000 indledte UNESCO (2000) en bevæegelse for uddannelse for alle. Dette medførte blandt andet et fokus på Open Educational Resources (OER), der ligeledes satte gang i en bevægelse (UNESCO, 2002). Den centrale idé med OER er at udnytte digitale medier til at stille ressourcer gratis til rådighed, idet digitale materialer kan kopieres og distribueres globalt (Caswell, Henson, J ensen and Wiley, 2008; Friesen, 2009). UNESCOs program kan med andre ord ses som en global forlængelse af tankerne bag åbne universiteter, der opererer på nationalt niveau. OER forlænger dermed de oprindelige tanker med åben uddannelse og uddannelse for alle med et særligt fokus på deling, tilgæengelighed og genanvendelighed i et globalt perspektiv (Windle, Wharrad, McCormick, Laverty and Taylor, 2010; Pegler, 2012). OER-bevægelsen har haft indflydelse på den globale uddannelsespolitik og har ligeledes haft stor betydning for udviklingen af metadata-standarder, digitale materialesamlinger og åbne licenser (Hylén, 2006). Et fremtrædende eksempel er MITs OpenCoursware, der blev annonceret i 2001.

I 2008 gennemførte George Siemens og Stephen Downes et åbent online kursus i “Connectivism and Connectivist Knowledge", hvor interesserede fra hele verden kunne deltage. Alle kunne tilmelde sig, og der var ingen deltagerbegrænsning eller adgangskrav. Dette kursus var centralt for, at der opstod en bevægelse omkring Massive Open Online Courses (MOOCs). MOOCs skal ligesom OER ses i sammenhæng med både åben uddannelse og Education for all, idet der til grund for etableringen af MOOCs ligeledes ligger et formål om at bringe uddannelse ud til målgrupper, der ellers har ringe adgang til uddannelse. Dermed ikke sagt, at der ikke også er andre motiver bag MOOCs, såsom markedsføring ogPR.

Erfaringerne med MOOCs har vist, at der er mange udfordringer forbundet med at åbne uddannelse til en stor målgruppe, og MOOCs er især blevet kritiseret for at have en meget lav gennemførelsesprocent (Chen, 2014; Daniel, 2012; Kizilcec, Piech, \& Schneider, 2013; Clow, 2013). Ifølge en undersøgelse af J ordan (2014) er der i gennemsnit 43.000 studerende, der tilmelder sig en MOOC, mens kun ca. 6 \% 
gennemfører. Derudover har MOOCs mødt kritik for deres tvivlsomme forretningsmodeller, eftersom det er en udfordring at skabe økonomisk balance i kurser, der skal være gratis for deltagerne (Daniel, 2012). Endelig er MOOCs blevet kritiseret for deres pædagogik. Selvom MOOCs efterhånden har fået mange udformninger, er der visse pædagogiske modeller, der dominerer MOOCs. Kritikken er primært retttet mod de såkaldte xMOOCs, der udgør langt den største del af MOOCs. xMOOCs er betegnelsen for MOOCs, der udbydes gennem fx Coursera og EdX (Siemens, 2013). Som modspil hertil anvendes betegnelsen cMOOCs om MOOCs, der ligner den "oprindelige" MOOC baseret på connectivism (Siemens, 2013). Daniel (2012) skriver i sin kritik af xMOOCs, at de anvender metoder for online uddannelse, der går 40 år tilbage i tiden. Det er metoder, der primært er baseret på underviservideoer, fokus på individuel læring, quizzer og tests (Chen, 2014; Dolan, 2014).

I Danmark har ideen om MOOCs vundet fodfæeste på de fleste videregående uddannelsesinstitutioner. F.eks. har Københavns Universitet indgået et samarbejde med Coursera (https:// moocs.ku.dk/), som er en af de større kommercielle MOOC-platforme, og andre danske universiteter, bla. DTU, CBS og SDU har indgået lignende aftaler. Aarhus Universitet har ud over en række mindre MOOC-forløb været involveret i HOME-projektet (Higher education Online: MOOCs the European way. Se https://home.eadtu.eu/), der har fokus på at styrke og udvikle et europæisk netværk omkring åben uddannelse, herunder MOOCs. Det indebærer blandt andet udvikling af en bæredygtig forretningsmodel, der ikke er funderet i kommercielle interesser. Også ved professionshøjskolerne er MOOCs blevet indlemmet i undervisningsporteføljen, som en måde at tilbyde formel undervisning på. Det ses bla. i en antologi redigeret af Nortvig og Hestbech (2016), der beskæettiger sig indgående med MOOCs på Professionshøjskolen Absalon (dengang UC Sjælland).

En stor del af kritikken af MOOCs kommer fra et perspektiv om traditionel uddannelse, hvor eksempelvis gennemførelsesprocenter er af stor betydning. Som de Langen og van den Bosch (2013) argumenterer for, er det imidlertid vigtigt ikke at betragte MOOCs som et alternativ eller en erstatning af traditionel uddannelse, men at de nærmere kan udgøre et supplement med andre muligheder (Ho et al., 2015). Fx argumenterer Littlejohn, Hood, Milligan \& Mustain (2016) for, at et ensidigt fokus på progression og gennemførelse kan få os til at overse nye læringsmuligheder.

Littlejohn \& Hood (2018) sætter spørgsmålstegn ved den udbredte antagelse bag kritikken af MOOCs om, at gennemførelse er den bedste måde at deltage og lære på. De peger omvendt på, at MOOCs potentialer netop ligger i, at det er muligt at deltage på andre måder. En række studier har undersøgt, hvordan MOOC-studerende deltager på ikke-traditionelle måder i kursusforløbene. Milligan, Littlejohn og Margaryan (2013) identificerede tre former for deltagelse; aktiv deltagelse, passiv deltagelse og "lurking". Både Littlejohn, Hood, Milligan, and Mustain (2016) og Milligan og Littlejohn (2017) viser, at MOOCs tiltrækker deltagere med meget forskellige motiver og mål for deltagelse, hvilket har betydning for, hvordan den enkelte tilgår og opfatter kurset. En undersøgelse i Kizilcec, Piech \& Schneider (2013) af sub-populationer i MOOCs viste ligeledes, at gennemførelse ikke er den eneste frugtbare måde at deltage i MOOCs på. Undersøgelsen identificerede fire grundlæggende deltagelsesformer: completing, auditing, disengaging og sampling. En central konklusion hos Kizilcec, Piech \& Schneider (2013) er, at der var tilfredse deltagere inden for alle fire deltagelsesformer. For eksempel gav auditing-gruppen udtryk for, at de havde fået meget ud af deres deltagelse på trods af, at ingen af dem havde gennemført kurset.

I denne artikel sætter vi fokus på de ovenfor identificerede, uddannelsesmæessige potentialer i åbne, online kurser for at understøtte variation i studerende, der deltager med forskellige motiver og læringsmål, og som bringer deres egne professionelle erfaringer med i forløbet. Artiklen præesenterer en kvalitativ undersøgelse, der har til formål at undersøge uddannelsesmæessige potentialer knyttet til usynlige studerende. 


\section{Undersøgelse}

\section{Forskningsspørgsmål}

Baseret på ovenstående review har vi formuleret følgende forskningsspørgsmål:

1. Hvilke deltagelsesformer er til stede i MOOC-forløbet?

2. Hvordan lærer de usynlige studerende i forløbet?

3. Hvad lærer de usynlige studerende i forløbet?

Forskningsspørgsmålene behandles gennem en empirisk undersøgelse, hvis mål er at undersøge forskellige deltagelsesformer, og som dernæest undersøger de usynlige studerendes aktiviteter, behov og udbytte.

\section{OOC-designet}

Som næunt ovenfor bunder etablerede uddannelsesinstitutioners interesse i MOOCs ofte i potentialet for formel uddannelse af de mange og dermed er der fokus på gennemførelsesraterne. Dette fokus overser dog ofte deltagere, der bruger kursets indhold og aktiviteter på andre måder end dem, der resulterer i et bestået resultat (Ho et al, 2015). For at undersøge denne gruppe af deltagere tager dette studie udgangspunkt i at designe et åbent online undervisningsforløb. Inspireret af MOOCs og særligt Kizilcec, Piech \& Schneiders (2013) opdeling af MOOC-deltagere i completing, auditing, disengaging og sampling undergrupper var målet at designe et forløb, der kunne understøtte mange forskellige måder at deltage på. Fokus var ikke på at opnå mange deltagere, hvorfor vi har valgt at omtale forløbet som et OOC (Open Online Course) og undlade betegnelsen Massive. Forløbet var imidlertid stadig skalerbart og kunne principielt rumme tusindvis af deltagere, såfremt interessen og ressourcerne var til stede.

Den faglige ramme for forløbet var faget "Digitale Læringskontekster", der er en del af kandidatuddannelsen i IT-didaktisk design på Aarhus Universitet. Faget er på 20 ECTS-point og er det første fag, de studerende møder på uddannelsen. En del af dette fag blev designet som et åbent online forløb, hvor de indskrevne studerende blev akkrediteret for deres gennemførelse som et af flere elementer i et større fag, men ellers skulle de følge forløbet på lige fod med de eksterne deltagere.

For at understøtte flere deltagelsesformer end de traditionelle producerende og diskuterende var det nødvendigt at åbne forløbet. Alle opgaver, fagtekster, videoer, streamede vejledningssessioner, deltagerproduceredeblogindlæg og-kommentarer og fælles diskussioner mellem deltagere, undervisere og eksterne ressourcepersoner lå frit tilgængeligt online. Denne åbenhed gjorde det nemt at følge med i forløbets opgaver, at deltage i diskussioner og at overvære vejledninger og underviseroplæg uden at registrere sig og forpligte sig på noget.

Behovet for åbenhed stillede krav til forløbets platform, som hverken det lokale LMS eller en traditionel MOOC-platform kunne honorere. Den designmæssige konsekvens af disse forhold blev, at forløbet blev bygget på en WordPress-platform (Content Management System), der fungerede som et samlende hub, hvor forløbets andre digitale medier og værktøjer forbandt sig med hinanden i, hvad der kunne karakteriseres som en medieøkologi (McLuhan, 1964; Postman, 2000; Scolari, 2012; Baym, 2015). Disse omfattede ud over WordPress også Google Suite for Education, en Facebook-gruppe, YouTube, Hangout on Air, Todaysmeet, Twitter med mere.

Forløbet søgte at skabe et fælles rum for eksperimenter og undersøgelse, inspireret af Garrisons (2016) begreb om "undersøgende fællesskaber" (engelsk: "community of inquiry", vores oversættelse). Disse er forankret i Deweys (1933) forståelse af læring som en praktisk, reflekterende undersøgelse, der udspiller 
sig i et fællesskab og søger at skabe et rum, hvor deltagerne kan brydes med det faglige indhold primært gennem aktiviteter, der bygger på eksperimenter og diskussioner. Konkret foregik det ved at lade deltagerne undersøge en praksis, typisk gennem observationer og interviews, analysere det indsamlede empiriske materiale, forfatte blogindlæg med analyser, skrive kommentarer til hinandens blogindlæg og endelig reflektere over processen i et fælles rum både synkront og asynkront. Ved siden af disse eksperimenter i praksis erhvervede deltagerne teoretisk viden ved at læse faglitteratur, blogindlæg og videoer udvalgt af kursets underviser og designere. Alle aktiviteter var i udgangspunktet designet til at blive udført som samarbejde i grupper, men kunne for nogles vedkommende også gennemføres individuelt.

En række principper for undervisningsaktiviteter var centrale for designet af OOC'en:

* Produktion, deltagerne blev bedt om at skabe en række produkter i form af tekster, videoer og fotografier. Centralt var blogindlæg, som redegjorde for undersøgelser af praksis.

* Selvstændig tilegnelse af viden, en anseelig del af deltagernes arbejde med OOC'en indebar at læse litteratur, se videoer og forholde sig til andre deltageres blogindlæg og kommentarer.

* Refleksioner, deltagerne blev bedt om at reflektere over undersøgelserne og litteratur primært i blogindlæg, men også i kommentarer til andre deltageres blogindlæg.

* Diskussioner, deltagerne blev inviteret til at deltage i faglige diskussioner i forbindelse med gruppevejledninger, i kommentarsporet på bloggen samt i studiegrupperne, hvor de skulle opnå en fælles forståelse af den konkrete undersøgelse.

Efterhånden som forløbet skred frem blev der produceret en stadigt voksende mængde indhold, der tiltrak interessenter fra andre områder inden for feltet. Indholdet blev spredt via forskellige digitale kanaler af deltagerne selv, af underviserne og af tilskuere, der faldt over platformen i deres egne afsøgninger af internettet. Disse interessenter bidrog i nogle tilfælde med faglige indspark og vurderinger. I nogle tilfælde tilføjede de ligefrem reelt fagligt indhold til forløbet. Disse forhold kan karakteriseres som et set (Dron \& Anderson, 2014), en samling af mennesker og artefakter, der deler den samme attribut, i dette tilfælde en interesse for brug af teknologi i undervisningen.

\section{Metode}

Den empiriske undersøgelse er primært et kvalitativt studie af MOOC-deltagernes aktiviteter. Undersøgelsen består først og fremmest af 11 interviews med MOOC-deltagere og suppleres af en mindre spørgeskemaundersøgelse besvaret af 51 deltagere. Der er tale om en kvalitativ undersøgelse, der ikke sigter mod et generaliserbart billede af usynlige studerende, men derimod om at få et dybdegående indblik i usynlige studerendes forskellige deltagelsesformer og læringsudbytte. Spørgeskemaundersøgelsen blev udsendt til samtlige deltagere umiddelbart efter kurset og skulle primært bidrage til at besvare det første forskningsspørgsmål. Formålet med spørgeskemaundersøgelsen var at etablere et overblik over, hvilke aktiviteter deltagerne havde gennemført, at bidrage til at forstå, i hvor høj grad de havde deltaget i forskellige aktiviteter samt at undersøge deres vurdering af udbyttet. Spørgsmålene i spørgeskemaet baserede sig på OOC'ens forskellige aktiviteter; skrive blogindlæg, kommentere på bloggen, læse litteratur, se underviservideoer, besvare opgaver og læese blogindlæg. Følgende spørgsmål fra spørgeskemaet er anvendt i indeværende analyse:

Hvordan vil du beskrive din generelle arbejdsindsats i forbindelse med kurset?
* J eg har været med gennem hele kurset
* J eg har været med i dele af kurset 
* J eg sprang helt fra undervejs

* J eg startede slet ikke og har ikke fulgt med

Hvordan vil du beskrive din overordnede deltagelse i kurset?

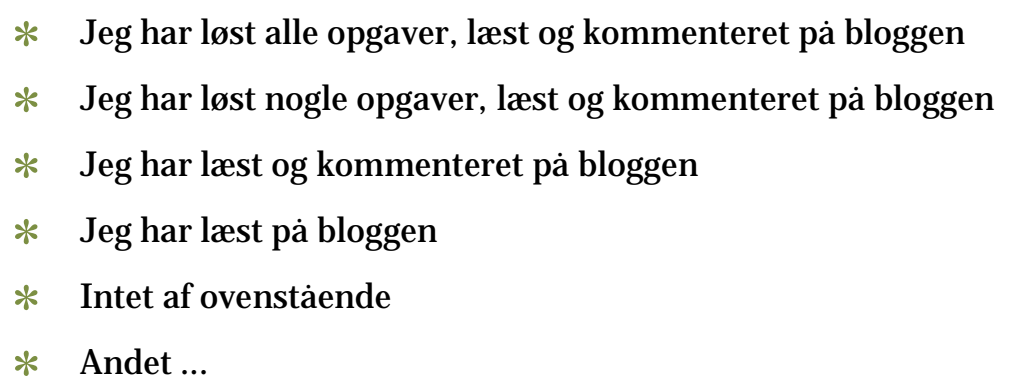

Hvor meget har du deltaget i følgende aktiviteter på kurset? (I meget høj grad - I væesentlig grad - I nogen grad - I ringe grad - Slet ikke - Ved ikke)
* Deltaget med kommentarer i diskussionerne på bloggen
* Bidraget til at skrive blogindlæg
* Læest litteraturen til kurset
* Set underviservideoerne til kurset
* Arbejdet med delopgaverne
* Læst blogindlæg

I hvor høj grad har du fået udbytte af at deltage i følgende aktiviteter på kurset? (I meget høj grad - I væesentlig grad - I nogen grad - I ringe grad - Slet ikke - Ved ikke)
* Bidrage til at skrive blogindlæg
* Deltage med kommentarer i diskussionerne på bloggen
* Læese litteraturen til kurset
* Se underviservideoerne til kurset
* Arbejde med delopgaverne
* Læse blogindlæg

På baggrund af det andet og tredje forskningsspørgsmål blev en interviewguide udarbejdet (se tabel 1). Spørgeskemaet indeholdt også enkelte åbne spørgsmål, der bidrog til at besvare det andet og tredje forskningsspørgsmål (disse spørgsmål er inkluderet i tabel 1). De 11 interviewpersoner blev udvalgt med det formål at repræesentere en variation i deltagelsesformer. Interviewpersonerne blev derfor udvalgt på baggrund af deres aktiviteter på bloggen, i kursets Facebook-gruppe og i Google Drive. 
Tabel 1. Interviewguide (inkl. åbne spørgsmål fra spørgeskemaet).

\begin{tabular}{|l|l|}
\hline Tema & Interviewspørgsmål \\
\hline Deltagelsesformer & $\begin{array}{l}\text { Hvorfor ville du gerne deltage i (M)OOC'en? } \\
\text { Hvad har du gjort i (M)OOC'en? } \\
\text { Kan du beskrive, hvordan du har deltaget i (M)OOC'en? } \\
\text { Hvordan så din dag ud i den periode I lavede opgaver? } \\
\text { Hvad er det for et miljø/ rum, du har deltaget i? }\end{array}$ \\
\hline $\begin{array}{l}\text { Anvendelses- og } \\
\text { udbytteformer }\end{array}$ & $\begin{array}{l}\text { Hvis du skal fremhæve noget, som du synes har været særligt } \\
\text { interessant og spændende for dig ved (M)OOC'en, hvad kunne det så } \\
\text { være? } \\
\text { Hvad har du fået ud af deltagelsen? / Hvad har du lært? } \\
\text { Hvad har du anvendt i forløbet? } \\
\text { Står udbyttet mål med din deltagelse? } \\
\text { Fra spørgeskemaet } \\
\text { Beskriv kort, hvad du har fået ud af at deltage i (dele af) kurset. } \\
\text { Hvordan har kurset været relevant for din egen praksis/ hverdag? } \\
\text { Giv gerne et eksempel på, hvordan du har anvendt noget fra kurset i } \\
\text { din egen praksis/ hverdag. }\end{array}$ \\
\hline $\begin{array}{l}\text { Kommunikation } \\
\text { mellem deltagerne }\end{array}$ & $\begin{array}{l}\text { Hvordan har du oplevet den faglige kommunikation/ udveksling } \\
\text { mellem deltagerne? } \\
\text { Hvordan vil du beskrive din eller din gruppes } \\
\text { interaktion/ kommunikation med de indskrevne studerende? } \\
\text { Hvordan har du forholdt dig til gruppearbejdet? } \\
\text { Hvordan har I arbejdet sammen i din gruppe? }\end{array}$ \\
\hline opkvalificering & $\begin{array}{l}\text { Hvad var dit formål eller motiv med at deltage i OOC'en? } \\
\text { Hvordan holder du dig generelt opdateret, făr input og inspiration? } \\
\text { Hvordan bliver du bedst opkvalificeret/ uddannet? }\end{array}$ \\
\hline
\end{tabular}

\section{Databehandling}

Interviewene blev delvist transskriberet og behandlet gennem en tematisk analyse (Braun \& Clarke, 2006; Guest, MacQueen, \& Namey, 2011), der også indbefattede svarene på de åbne spørgsmål i spørgeskemaet. Analysen tog afsæt i Braun \& Clarkes (2006) seks faser i en tematisk analyse: 1) etablering af fortrolighed med det empiriske materiale, 2) etablering af foreløbige koder, 3) søgning efter temaer, 4) vurdering af temaer, 5) definition og navngivning og 6) afrapportering. Konkret betød dette, at interviewene blev lyttet igennem og analyseret på baggrund af andet og tredje forskningsspørgsmål, og citater, der relaterede sig til forskningsspørgsmålene, blev transskriberet. Dernæst blev transskriptionerne kodet med fokus på, hvordan og hvad deltagerne lærte. Koderne blev samlet og analyseret med henblik på at kategorisere dem i temaer. Endelig blev temaerne vurderet med henblik på en endelig definition og navngivning. 


\section{Resultater}

\section{Studerende, deltagere, medlemmer, observatører og gæster}

Spørgeskemaundersøgelsen blev udsendt til 165 deltagere og besvaret af 51, hvoraf de 11 ikke havde påbegyndt kurset. Da disse 11 ikke har deltaget i nogle of kursusaktiviteterne, er de trukket ud af nedenstående analyse.

For at afdække forskellige deltagelsesformer (første forskningsspørgsmål) tildeltes point (fra 0-4) til svarene på spørgsmålet "Hvor meget har du deltaget i følgende aktiviteter på kurset?". Derefter blev deltagerne sorteret efter deres samlede aktivitetsniveau. Denne sortering viste, at der var stor variation i deltagernes aktiviteter (fra 1 til 32 point). Der er en tendens til, at dem der har deltaget i flest aktiviteter, også har deltaget mest inden for de enkelte aktiviteter. Imidlertid er der også eksempler på deltagere, der har deltaget meget i få aktiviteter. Spørgeskemaundersøgelsen giver ikke en entydig kategorisering af deltagerne. Med inspiration fra Kizilcec, Piech \& Schneider (2013) er det dog muligt at skelne mellem nogle overordnede deltagelsesformer, nemlig følgende:
* Studerende
* Deltagere
* Medlemmer
* Observatører
* Gæester

Betegnelsen studerende dækker over de indskrevne studerende, der følger ECTS-kurset. Deltagere er eksterne OOC-tilmeldte, hvis aktiviteter spejler de indskrevne studerende, idet de også udfører kursusaktiviteterne og gennemfører kurset. Medlemmer er deltagere, der måske laver enkelte opgaver og kommenterer på bloggen, men som ikke gennemfører alle kursusaktiviteterne. Observatører dækker over deltagere, der ikke laver opgaver, ikke deltager i diskussioner, men primært orienterer sig i kursuslitteratur, blogindlæg og videoer. Endelig er der deltagelsesformen gæster, der dækker over en gruppe af ikke-registrerede, som tilgår enkelte dele af kursusmaterialet.

\section{Usynlige vs. synlige studerende}

Som udgangspunkt for at besvare det andet og tredje forskningsspørgsmål om usynlige studerende, inddelte vi deltagernes aktiviteter i synlige og usynlige. De synlige aktiviteter indbefatter at skrive blogindlæg og kommentere på blogindlæg, mens at læese litteratur, se videoer, arbejde på opgaverne og læse blogindlæg udgør de usynlige aktiviteter. På baggrund af denne inddeling kan deltagerne grupperes i synlige og usynlige studerende. Ud af de 40 deltagere i spørgeskemaundersøgelsen var de 17 synlige, mens 23 udelukkende deltog i usynlige aktiviteter. I spørgeskemaet spurgte vi inden for hver aktivitet til, "I hvor høj grad har du fået udbytte af at deltage i følgende aktiviteter på kurset?”. På baggrund af svarene på disse spørgsmål blev det vægtede gennemsnit af samtlige deltageres erfarede udbytte beregnet. Det vægtede gennemsnit er alene beregnet ud fra de aktiviteter, deltagerne har udført. Af beregningen fremgår det, at de synlige studerende generelt har erfaret det største udbytte, men at flere af de usynlige studerende samtidig har oplevet et relativt højt udbytte. Dette resultat peger på, at de usynlige studerende har oplevet at få noget ud af kurset på trods af deres begræensede deltagelse, hvilket gør det relevant at undersøge nærmere, hvordan og hvad de lærer. 


\section{Hvordan lærer usynlige studerende?}

Spørgsmålet er, hvordan de usynlige studerende beskriver deres læring og læringsaktiviteter; hvordan har de arbejdet gennem forløbet? Kodningen af interviewene ud fra det andet forskningsspørgsmål gav følgende kategorier til at beskrive deltagernes læringsaktiviteter:
1. Læese og gennemse
2. Følge og være en del af
3. Netværke
4. Reflektere
5. Anvende

Nedenfor udfoldes disse kategorier med citater fra interviewene (alle navne på interviewpersonerne er ændret til fiktive navne).

\section{1) Læse og gennemse}

Det fremgår af både spørgeskemaundersøgelsen og interviewene, at de usynlige studerende primært læser kursuslitteraturen, gennemser underviservideoer og læser blogindlæg skrevet af de synlige studerende. Det er vigtigt at bemærke, at nogle af de usynlige studerende har været med gennem hele kursusforløbet og på den måde ikke er faldet fra - selvom de heller ikke har gennemført.

J eg har set alt det, jeg overhovedet kunne se. Og litteraturen har jeg sådan orienteret mig i. (John)

\section{2) Følge og være en del af}

De usynlige studerende har ikkealeneværet på kort visit på kursushjemmesiden og downloadet relevant materiale, før de så har forladt kurset igen. I stedet giver de i interviewene udtryk for, at de har fulgt med i kurset fra sidelinjen. Flere af de usynlige studerende fortæller, at de har været med og fulgt kurset sammen med de synlige studerende. Med andre ord har de usynlige studerende fulgt processen og progressionen i kurset, blandt andet ved at følge med i de løbende diskussioner mellem de synlige studerende og underviseren.

Man altid vidste det der med, at man kunne gå ind og kigge på tingene og læse, og der kom nye ting. (Susanne)

Det [at deltage i kurset] var ligeså meget også bare for og koble sig lidt på, og se hvad der skete og få noget viden om de her ting. (Peter)

At kunne være med $\mathrm{i}$ et uddannelsesforløb, hvor det egentligt var virkeligt ok at være bænkevarmer, for det er det jeg har været. Og har fået værdifuld læring på sidelinjen. (John)

Flere af de usynlige studerende fortæler, hvordan de gennem kursusforløbet har oplevet at være en del af noget - fx nævner flere deltagere, at de betragter kurset som en form for "digitalt fællesskab”.

På blog-delen har jeg luret og fundet inspiration. Men på Facebook-delen ... det jeg synes, at den tilbyder mig, det er et fællesskab. Her er vi i et fællesskab. (J ohn)

Men sådan at man kan finde ligesindede, der også synes, at det her det er bare det fedeste at snakke om i sammenhængen. (Laura) 
Så jeg tænkte, endelig kan jeg være sammen med nogen, som taler fagsprog, og som også har den interesse. (Stig)

Deltagerne har med andre ord ikkealene opfattet kurset som en statisk ressource eller materialesamling, hvor de kan finde og udvælge ressourcer. De giver udtryk for, at de har oplevet at være en del af et forløb og nogle processer, der har udfoldet sig på kurset.

\section{3) Netværke}

Mange af de interviewede usynlige studerende fortæller, at de blandt andet har deltaget i kurset med henblik på at udvide deres personlige netværk. Et mål med deres deltagelse har været, at de gerne vil have adgang til personer, der arbejder inden for kursets fagområde. De usynlige studerendes deltagelse kan på den måde minde om deltagelse i en konference, hvor man lytter til og møder personer inden for et bestemt fagområde.

\footnotetext{
Den der med at dyrke sit netværk og sparre med andre mennesker og få andres holdninger til de ting man selv sidder og synes man har en ret fastlåst mening om. (Laura)

At sparre med nogen, der har den samme interesse som mig. (Susanne)

For mig er det jo svært at finde inspiration ret mange steder. At blive inspireret og have netværk og de der ting. (Susanne)
}

At udvide sit netværk giver ikke nødvendigvis et umiddelbart læringsudbytte i form af mere viden, men et netværk kan styrke deltagernes muligheder for på læengere sigt at trække på fagfæller i forskellige sammenhænge.

\section{4) Reflektere}

De usynlige studerende giver udtryk for, at de også bruger kursets indhold og diskussioner til at spejle og reflektere over deres egen viden og deres egen praksis. Nogle af deltagerne giver udtryk for, at de ønsker at afprøve eller provokere deres egne forståelser og opfattelser.

Så er det jo også rart at få nogle folk ind med den nyeste teoretiske viden på området, som kan bidrage med noget nyt og som også i gåseøjne kan provokere os en lille bitte smule. (Susanne)

Særligt værktøjerne der blev anvendt gav anledning til refleksion over muligheder og hvilke der var brugbare i mit miljø eller hvorvidt jeg skulle overveje andre og tilsvarende produkter. (Fra spørgeskema)

J eg har brugt min erfaring fra forskellige undervisningsforløb som horisont for såvel teori som cases i kursets referenceliste. (Fra spørgeskema)

\section{5) Anvende}

I både interviews ogi besvarelserne i spørgeskemaet fremgår det, at de usynlige studerende helt konkret anvender indhold fra kurset i deres egen praksis. De usynlige studerende er med andre ord ikke inaktive beskuere af kurset, men er aktivt udøvende - blot i deres egen praksis. Deltagerne giver udtryk for, at de med baggrund i input fra kurset udfører noget i deres egen praksis. Det er en central pointe, at de usynlige studerende så at sige har flyttet læringsaktiviteterne ud af kurset og ind i deres egen praksis og profession. Disse aktiviteter er blot ikke synlige inden for kurset og for underviseren. 
J eg har brugt nogle af de modeller jeg er blevet præsenteret for på kurset i evalueringen af mine egne arbejdsopgaver. (Fra spørgeskema)

Jeg har benyttet Powtoon i min undervisning. Eleverne skulle bruge programmet. (Fra spørgeskema)

Dette har jeg eksperimenteret med i eget webinar. (Fra spørgeskema)

Selvom de usynlige studerende ikke bidrager til kurset med opgaver eller diskussion, betyder det ikke, at de er inaktive. Interviewene viser, at nogle af de usynlige studerende har udført aktiviteter i deres egen praksis med afsæt i deres deltagelse i kurset. De aktiviteter eller "opgaver", som de usynlige studerende udfører, er blot ikke defineret af kurset, men udspringer af deres egen praksis.

Af interviewene fremgår det, at de usynlige studerende viser tegn på meget selvstæendige læringsaktiviteter, hvilket Littlejohn et al. (2016) ligeledes fremhæver. Det er en central pointe, at de usynlige studerende ikke ønsker at tage del i traditionelle kursusaktiviteter med faste opgaver og læringsmål. I stedet foretrækker de at tage afsæt i deres egen praksis og ud fra denne afgøre, hvad der er relevant for dem.

\section{Hvad lærer usynlige studerende?}

Kodningen af interviewene ud fra det tredje forskningsspørgsmål gav følgende tre kategorier:

1. Inspiration

2. Opdatering

3. Input til praksis

Fælles for de interviewede usynlige studerende var, at ingen af dem havde nogen præcis opfattelse eller beskrivelse af, hvad de havde til hensigt at lære. En af deltagerne formulerede det således:

Men gad vide om jeg ikke har lært lige præcis det jeg skulle. Jeg har bare ikke været bevidst om, hvad det var jeg skulle lære. (J ohn)

\section{1) Inspiration}

Mange af de usynlige studerende siger direkte, at de ikke deltager i kurset for at lære et bestemt indhold. I stedet deltager de med henblik på at få inspiration gennem kursets indhold og aktiviteter. De følger med i kurset på udkig efter nye idéer og nye perspektiver.

At få det der ekstra, som man ikke kan google sig til. (Laura)

J eg bruger det egentligt som inspiration og ny viden og synes egentligt, at det er dejligt det her med at bare kunne være tilstede uden at skulle være aktiv deltagende. (J ohn)

Gennem de tekster som jeg har læst har jeg fået nogle nye perspektiver, som jeg vil arbejde videre med. (Fra spørgeskema)

Denne form for deltagelse og interesse i kurset betyder, at deltagerne ikke nødvendigvis er interesseret i, hvad kurset har til hensigt at lære dem. For eksempel siger nogle af interviewpersonerne, at de ikke har haft til hensigt at besvare kursusopgaverne. Dette betyder også, at de usynlige studerende selv definerer deres læringsmål. 


\section{2) Opdatering}

Flere af interviewpersonerne fortæler, at de deltager i kurset med et ønske om at blive opdateret inden for deres fagområde. De ønsker at vide, hvad der er nyt inden for deres område, og de vil gerne vide, hvad de ikke ved, og hvad de bør vide mere om. Det er ikke nødvendigvis en viden, de skal bruge eller handle på nu, men en baggrundsviden der er relevant for dem at have og være orienteret om.

Det handler jo om hele tiden at holde sig opdateret og være med på tingene. (Peter)

Måske blive lidt opdateret, når jeg måske godt vidste, at det her med at komme til at gennemføre sådan nogle opgaver, det bliver måske lidt for meget. (Peter)

\section{3) Input til praksis}

Det er karakteristisk for de usynlige studerende, at de sorterer i kursets indhold ud fra, hvad der er relevant for deres egen profession, og nogle af dem efterspørger specifikt anvendelig viden.

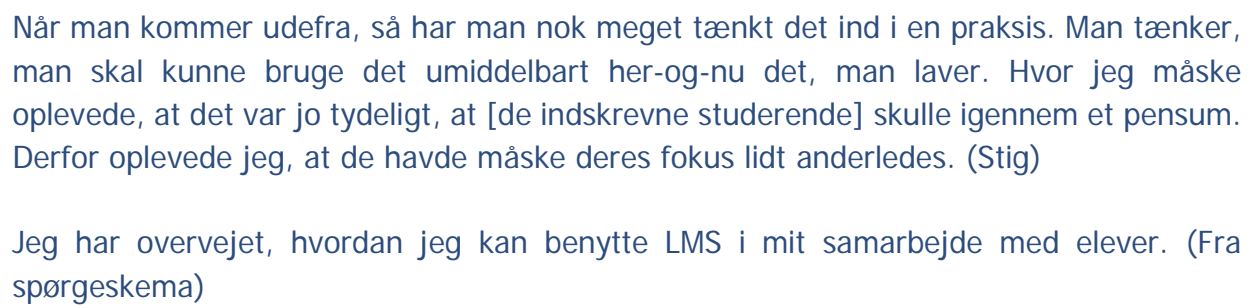

En central pointe om, hvad de usynlige studerende lærer, er at de ikke har lært, hvad kurset har haft til hensigt at lære dem. De usynlige studerende havde ikke et ønske om at tilegne sig det specifikke kursusindhold, og det var samtidig ikke klart for dem, hvad de rent faktisk gerne ville lære. De deltog med henblik på at få input og inspiration, og ifølge dem selv endte de med at lære noget, der var relevant og meningsfuldt for dem.

\section{Diskussion: Nye (efter)uddannelsesformater}

OOC-designet havde til hensigt at etablere et undersøgende fællesskab mellem deltagerne. Idet en række deltagere løste de stillede opgaver, bidrog med blogindlæg og deltog i diskussioner, kan man argumentere for, at der blev skabt en form for undersøgende fæallesskab mellem deltagerne. Centrale karakteristika ved sådan et fællesskab er, at deltagerne udforsker nye idéer og giver hinanden gensidig support og konstruktiv feedback (Garrison, 2016), hvilket kunne identificeres i kurset.

Imidlertid kan det ikkehævdes, at de usynlige studerende har været en del af et undersøgende fællesskab inden for kurset. Det fremgår af interviewene og besvarelserne af spørgeskemaet, at de usynlige studerende oplever sig tilknyttet kurset, idet de følger med i aktiviteterne, men de gør det uden et aktivt engagement og undersøgelse ind i kurset. Med andre ord udviser de usynlige studerende umiddelbart en traditionel "lurker"-adfærd (Alexander \& Fink, 2018; Milligan, Littlejohn, \& Margaryan, 2013). Samtidig viser undersøgelsen, at de usynlige studerende ikke udelukkende er passivelurkere, tværtimod viser især kategorierne "anvende" og "input til praksis" beskrevet ovenfor, at de har anvendt kurset inden for deres egen praksis og til deres egne formål. Dette peger på, at de usynlige studerende er aktive, bare ikke inden for rammerne fastsat af kurset. Mens de synlige studerende foretager undersøgelser (inquiry) inden for kursets rammer gennem opgaver og blogindlæg, foretager de usynlige studerende undersøgelser i deres egen praksis uden for kursets kontekst.

På den baggrund kunne man konkludere, at de usynlige studerende ikke har brug for et kursus, men alene søger materialer. Det er imidlertid vigtigt at understrege, at de usynlige studerende har fulgt med 
i de kursusaktiviteter, der er udsprunget af de synlige studerende. De synlige studerende sørgede for et aktivitetsniveau, der var så tilpas stort, at det var interessant for de usynlige studerende at følge med. De åbne og tilgæengelige aktiviteter fra de synlige studerende har med andre ord bidraget til de usynlige studerendes interesse i forløbet, og de har medvirket til, at de løbende har vendt tilbage til kurset.

Resultaterne af undersøgelsen viser, at et kursus som format (med opgaver og læringsmål) ikke er velegnet til de usynlige studerende, idet de ikke ønsker at besvare opgaver og forfølge bestemte læringsmål. Samtidig viser undersøgelsen, at aktiviteterne på kurset har skabt en meningsfuld ramme; kurset har skabt et narrativ og en form for vidensfællesskab, der på den ene side fastholder de usynlige studerendes interesse og på den anden side bidrager med input til deres kontekst.

Den måde hvorpå de usynlige studerende lærer viser, at de er i stand til selvstændigt at gennemføre og styre egne læringsaktiviteter. Samtidig er deres deltagelse kendetegnet ved, at de medbringer deres egen praksis og profession, og at de er i stand til selv at definere deres opgaver i form af problemer og mål fra egen praksis. Vi kan pege på de usynlige studerende som en særlig målgruppe, der har været i stand til at træakke kursets indhold ind i egen praksis. Det er en målgruppe, der søger en form for efteruddannelse eller faglig opkvalificering. Undersøgelsen peger dermed på, at der er nogle særlige potentialer i åbne, online forløb i forhold til efteruddannelse. Denne målgruppe vil typisk stå oven på både en uddannelse og en professionel praksis, som danner udgangspunkt for deres behov for opkvalificering, og kan dermed have meget individuelle og specialiserede behov afhængig af arbejdsmæssig kontekst.

De usynlige studerendes deltagelsesformer imødekommes ikke særligt godt af traditionelle former for uddannelse, eftersom de usynlige studerende fx ikke efterspørger opgaver og fastlagte læringsmål. Nedenstående tabel opstiller nogle af forskellene mellem, hvad traditionel uddannelse indeholder og tilbyder, og hvad de usynlige studerende i kurset efterspørger.

\begin{tabular}{|l|l|}
\hline Traditionel uddannelse & Nye (efter)uddannelsesformater \\
\hline Opgaver og test & Mennesker og diskussioner \\
\hline Pensum & Vidensfællesskab \\
\hline Læringsmål & Input og inspiration \\
\hline Diplom/ eksamensbevis & Netværk \\
\hline
\end{tabular}

Ovenstående diskussion peger på, at en øget bevidsthed om og forståelse af usynlige studerendes deltagelsesformer kan danne udgangspunkt for udviklingen af nye (efter)uddannelsesformater, der i højere grad imødekommer usynlige studerendes behov og understøtter deres læringsaktiviteter. Det er ikke trivielt at skabe uddannelsesformater til de usynlige studerendes deltagelsesformer, og indeværende undersøgelser indeholder ikke svaret. Udfordringen ligger i at tilbyde højre side af tabellen, og den måske største udfordring er spørgsmålet om, hvordan man udvikler forløb, når man ikke (præcist) ved, hvad deltagerne skal lære.

\section{Konklusion}

Undersøgelsen af usynlige studerende har vist, at de ikke deltager på en måde, der afspejler kursets intentioner, og at de samtidig ikke nødvendigvis lærer, hvad kurset har som formål. De usynlige studerende udviser en selvstændig adfærd, hvor de udvælger og gør, hvad der er relevant for dem. Det kommer især til udtryk, når de usynlige studerende udfører læringsaktiviteter uden for kurset i deres egen praksis. 
Undersøgelsen har vist, at der er uddannelsesmæssige potentialer i de usynlige studerendes deltagelsesformer på trods af, at de ikke gennemfører de aktiviteter, som kurset lægger op til. Potentialet består ikke i at få de studerende til at gennemføre kurset på traditionel vis. I stedet ligger mulighederne $i$ at bidrage med input til deres kontekst, idet de usynlige studerende selv er i stand til at koble til og inddrage nye elementer i egen praksis.

Selvom undersøgelsen ikke indeholder svaret på, hvordan vi kan udvikle (efter)uddannelsesformater, der understøtter de usynlige studerendes deltagelsesformer, viser kurset, at der er muligheder i at åbne for adgang til eksisterende kursusaktiviteter. De usynlige studerende har haft adgang til og har kunnet anvende de aktiviteter og produkter, som de aktive og synlige studerende har stået for.

Det undersøgelsen peger på, er at der ligger muligheder i at åbne for eksisterende uddannelsesaktiviteter til en bredere målgruppe - men uden en forventning om, at den bredere målgruppe skal gennemføre kursusaktiviteterne som indskrevne studerende. I stedet kan adgangen til et åbent, undersøgende fæakesskab potentielt bidrage med input og inspiration til, at usynlige studerende engagerer sig i selvstændige læringsaktiviteter i deres egen praksis.

Resultaterne fra undersøgelsen rejser en række spørgsmål om, hvordan vi udvikler efteruddannelsesformater, der imødekommer usynlige studerendes deltagelsesformer. Det centrale spørgsmål er: Hvordan udvikler man formater, der tilbyder input og inspiration til deltagernes egen praksis uden at fastsætte, hvad de skal lære?

\section{Anerkendelse}

Designet af det åbne online forløb er foretaget i samarbejde med Pernille J erslev og lektor og underviser Klaus Thestrup, mens undersøgelserne er foretaget i samarbejde med Per Falkeborg.

\section{Referencer}

Alexander, I. D., \& Fink, A. (2018). Designing an Inclusive Intercultural Online Participatory Seminar for Higher Education Teachers and Professionals. In N. Bonderup Dohn, S. Cranmer, J.-A. Sime, M. de Laat, \&T. Ryberg (Eds.), Networked Learning: Reflections and Challenges (pp. 125- 148). Cham: Springer International Publishing. https:// doi.org/ 10.1007/978-3-319-74857-3_8

Baym, N. K. (2015). Personal connections in the digital age. J ohn Wiley \& Sons.

Braun, V., \& Clarke, V. (2006). Using thematic analysis in psychology. Qualitative Research in Psychology, 3(2), 77- 101. https:// doi.org/ 10.1191/ 1478088706qp063oa

Caswell, T., Henson, S., J ensen, M., \&Wiley, D. (2008). Open content and open educational resources: Enabling universal education. The International Review of Research in Open and Distributed Learning, 9(1).

Chen, Y. (2014). Investigating MOOCs through blog mining. The International Review of Research in Open and Distributed Learning, 15(2). https:// doi.org/ 10.19173/irrodl.v15i2.1695

Clow, D. (2013). MOOCs and the funnel of participation. The Third International Conference on Learning Analytics.

Daniel, J . (2012). Making sense of MOOCs: Musings in a maze of myth, paradox and possibility. J ournal of Interactive Media in Education, 2012(3). Retrieved from https:/ / www-jime.open.ac.uk/article/view/ 2012-18/

de Langen, F., \&van den Bosch, H. (2013). Massive open online courses: Disruptive innovations or disturbing inventions? Open Learning: The J ournal of Open, Distance and e- Learning, 28(3), 216-226.

Dewey, J . (1933). How we think: A restatement of the relation of reflective thinking to the educative process. DC Heath.

Dolan, V. L. (2014). Massive online obsessive compulsion: What are they saying out there about the latest phenomenon in higher education? The International Review of Research in Open and Distributed Learning, 15(2).

Dron, J \& \&Anderson, T (2014) Teaching Crowds: Learning and Social Media. Athabasca University Press. 
Friesen, N. (2009). Open educational resources: New possibilities for change and sustainability. The International Review of Research in Open and Distributed Learning, 10(5).

Garrison, D. R. (2016). Thinking Collaboratively: Learning in a Community of Inquiry. New York: Routledge. https:// doi.org/ 10.4324/9781315740751

Guest, G., MacQueen, K. M., \& Namey, E. E. (2011). Applied thematic analysis. Sage Publications.

Ho, A., Chuang, I., Reich, J., Coleman, C., Whitehill, J., Northcutt, C., ...Petersen, R. (2015). HarvardX and MITx: Two Years of Open Online Courses Fall 2012-Summer 2014. https:// doi.org/ 10.2139/ ssrn.2586847

Hylén, J . (2006). Open educational resources: Opportunities and challenges. Proceedings of Open Education, 4963.

J ordan, K. (2014). Initial trends in enrolment and completion of massive open online courses. The International Review of Research in Open and Distributed Learning, 15(1). https:// doi.org/ 10.19173/irrodl.v15i1.1651

Kizilcec, R. F., Piech, C., \& Schneider, E. (2013). Deconstructing disengagement: analyzing learner subpopulations in massive open online courses. In Proceedings of the Third International Conference on Learning Analytics and Knowledge (pp. 170- 179). ACM. https:// doi.org/ 10.1145/2460296.2460330

Littlejohn, A., \& Hood, N. (2018). Reconceptualising Learning in the Digital Age: The [Un]democratising Potential of MOOCs. Springer. https:// doi.org/ 10.1007/ 978-981-10-8893-3

Littlejohn, A., Hood, N., Milligan, C., \&Mustain, P. (2016). Learning in MOOCs: Motivations and self-regulated learning in MOOCs. The Internet and Higher Education, 29, 40-48. https:// doi.org/ 10.1016/j.iheduc.2015.12.003

Littlejohn, A and Pegler, C. (2014). Reusing Resources: Open for Learning. J ournal of Interactive Media in Education, 1(2). DOI: http:// dx.doi.org/ 10.5334/ 2014-02.

McAndrew, P. (2010). Defining openness: updating the concept of" open" for a connected world. J ournal of interactive Media in Education, 2, Art-10.

McLuhan, M. (1994) Understanding media: The extensions of man. (MIT eds.) MIT press, 1994.

Milligan, C., \&Littlejohn, A. (2017). Why Study on a MOOC? The Motives of Students and Professionals. The International Review of Research in Open and Distributed Learning, 18(2). https:// doi.org/ 10.19173/irrodl.v18i2.3033

Milligan, C., Littlejohn, A., \& Margaryan, A. (2013). Patterns of engagement in connectivist MOOCs. J ournal of Online Learning and Teaching / MERLOT, 9(2). Retrieved from http://jolt.merlot.org/vol9no2/abstracts.htm

Nortvig, A. M., Hestbech, A. M. (2016). Nye design for undervisning og uddannelse. København. Dafolo.

Pegler, C. (2012). Herzberg, hygiene and the motivation to reuse: Towards a three-factor theory to explain motivation to share and use OER. J ournal of Interactive Media in Education 2012(1):4, DOI: http:/ / dx.doi.org/ 10.5334/2012-04

Postman, N. (2000). The humanism of media ecology. Keynote address delivered at the Inaugural Media Ecology Association Convention, J une 16-17, Fordham University, NY.

Scolari, C. A. (2012). Media ecology: Exploring the metaphor to expand the theory. Communication theory, 22(2), 204-225.

Siemens, G. (2013). Massive Open Online Courses: Innovation in Education. Open Educational Resources: Innovation, Research and Practice, 5.

Simpson, O. (2013). Student retention in distance education: are we failing our students? Open Learning: The J ournal of Open, Distance and E-Learning, 28(2), 105- 119. https:// doi.org/ 10.1080/ 02680513.2013.847363

UNESCO, E. (2000). The Dakar framework for action: Education for all: Meeting our collective commitments. Dakar Senegal, 26-28.

UNESCO (2002). Forum on the impact of Open Courseware for higher education in developing countries final report. Retrieved from http:/ / unesdoc.unesco.org/ images/ 0012/ 001285/ 128515e.pdf

Windle, R.J., Wharrad, H, McCormick, D, Laverty, H \& Taylor, M.G. (2010). Sharing and reuse in OER: experiences gained from open reusable learning objects in health. J ournal of Interactive Media in Education, 1(4). DOI: http:// dx.doi.org/ 10.5334/ 2010-4 


\section{Christian Dalsgaard}

Lektor

Center for Undervisningsudvikling og Digitale Medier, Aarhus Universitet

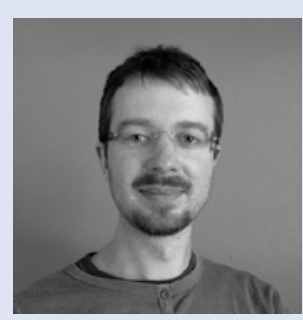

\section{Tom Gislev}

Videnskabelig assistent

Center for Undervisningsudvikling og Digitale Medier, Aarhus Universitet 